\title{
Sun Tzu's principles of war art and today's competition strategies: a relative approach
}

\author{
Izzet Kılınç $^{\mathrm{a}}$, Mehmet Akif Oncü ${ }^{\mathrm{b}}$, Yunus Emre Tasgit ${ }^{\mathrm{c} *}$ \\ ${ }^{a}$ Associate Professor, Duzce University, Faculty of Business, ${ }^{b}$ Assistance Professor, Duzce University, Faculty of Business, \\ ${ }^{c}$ Duzce University, Akçakoca Vocational School, Department of Tourism and Hotel Management,
}

\begin{abstract}
The purpose of this study is to associate with the principles of Sun Tzu's art of war and the basic features of the competitive strategies, and to reveal the similarities between Sun Tzu's war strategies and competitive strategies, to generate a different point of view for business and literature. Qualitative research method was used. Sun Tzu's art of war book was examined aspects of competition, and theoretical and practical secondary sources were evaluated. As a result, the Principles of Sun Tzu's art of war have been adapted to the business competitiveness, related to competitive strategies and created a conceptual framework.
\end{abstract}

Keywords: Competition, Competitive Strategy, Business World, Sun Tzu, the Art of War

\section{(C) 2012 Published by SSBF.}

\section{Introduction}

Today's business world companies that have made themselves competitiveness games show similarities to the struggles of armies fighting on the battlefield. In this respect, the principles of Sun Tzu's art of war can create perspective for players operating in the business world by correlating the basic features of the competitive strategies and give different perspectives in terms of theory and practice.

Considering the business world as a battlefield, the book "The Art of War", written by a Chinese philosopher named Sun Tzu, can be accepted as one of the most important references. If this reference is evaluated in terms of strategic management and competition strategies, it will give the company managers important clues in the process of developing and implementing strategies in the cases where there are no allied relations.

The global changes in the late 1980s affected the relations in the business world and the understanding of competition. The firms which do not develop strategies could be exposed to a market environment in which they may be eliminated, even if they are old, well-known, experienced, and using the latest techniques (James, 1985). For instance, General Motors' being defeated by the Japanese in the U.S.A automobile market can be evaluated in this context. For some researchers, the business world (market) has turned to be a battlefield (Kolar \& Toporišic, 2007). Beyond being able to compete, the companies need to have surcompetitive (Bono, 2000) and hyper-competitive (D'Aveni, 2005) strategies. The strategies which reflect the natural fighting characteristics of market environment have been needed more than before. The most suitable word to be used for the present market conditions is "war" (James, 1985).

On the point where we got, it is seen that there are important connections between war and today's competition environments, the business world and the fight field, and the principles of war and competition strategies. It is

\footnotetext{
* Corresponding author: Yunus Emre Tasgit, Tel: 0380611 8419. Fax: 0380611 8798. E- mail: yunusemretasgit@duzce.edu.tr
} 
essential to find out these connections in that it will bring a different point of view to the subject of competition strategies.

\section{Literature Review}

The literature of the strategic management being examined, it is seen that there are comprehensible studies involving strategic management subjects parallel to Sun Tzu's war art principles. For instance, Lin (1994) carried out some research on forming and implementing strategies by taking the war art principles into consideration. Wee and et al. (1991) studied the relationship between the war art principles and the concept of management. Wee (1994) examined war art principles in terms of strategic thinking and implementing them in business, and obtained positive results. Wu and et al. studied war art principles in respect of strategic management subjects such as case evaluation, implementing the strategies and strategic control, and tried to find out the relationship between the factors affecting the success of the organization and the harmony level among the concepts. As a result, he determined that there is a direct relationship between them. Lee and et al. (1998) studied Sun Tzu's principles under the methodology of quality function deployment, conducted a thorough search of their practicability in the business and management strategies, and claimed that the study results might be used as an indicator of performance. Tsang \& Lee (2002) examined the principles by integrating them into the characteristics of western management models and emphasized that the principles should be studied in a detailed way in order to obtain a strategic competition advantage. Lo and et al. (1998) found out that there was a meaningful relationship level in the study they carried out in Asia to designate the relationships between Sun Tzu's principles and strategic quality management. In addition to these studies, Ilicak \& Özgül (2005), in their study on war art and determining brand strategies, searched for the relationship between Sun Tzu's war art principles and components of brand strategy. They reached the conclusion that Sun Tzu's principles make a major contribution to the choice of brand strategy, its being well-known and to being successful at brand wars.

When the military management literature and business management literature were compared, it was found out that there were important similarities between them. These similarities especially focus on purpose/objective, forming the structure of the organization, stages of developing and implementing strategies. The criteria used in the comparison of the firms and armies have been given in Table 1.

Table 1: The Comparison of the Firms and Armies

\begin{tabular}{|l|l|l|}
\hline \multicolumn{1}{|c|}{ Firms } & Criteria & \multicolumn{1}{|c|}{ Armies } \\
\hline Obtain market share and control, & Objectives & Protect or conquer a region \\
\hline $\begin{array}{l}\text { Open systems affected by environmental (inner- } \\
\text { outer) changes, hierarchical structure, }\end{array}$ & Structure & $\begin{array}{l}\text { Open systems affected by environmental (inner- } \\
\text { outer) changes, hierarchical structure, }\end{array}$ \\
\hline $\begin{array}{l}\text { Have economic, social, political and ethical } \\
\text { principles to survive and succeed, }\end{array}$ & Principles & $\begin{array}{l}\text { Have economic, social, political and ethical } \\
\text { principles to survive and succeed, }\end{array}$ \\
\hline $\begin{array}{l}\text { Fulfil different strategic functions categorized } \\
\text { into sections according to their specialism, }\end{array}$ & Functions & $\begin{array}{l}\text { Fulfil different strategic functions categorized into } \\
\text { sections according to their specialism, }\end{array}$ \\
\hline $\begin{array}{l}\text { Benefit from methods related to different } \\
\text { disciplines in serving their functions, }\end{array}$ & Methods & $\begin{array}{l}\text { Benefit from methods related to different disciplines } \\
\text { in serving their functions, }\end{array}$ \\
\hline $\begin{array}{l}\text { Have certain attitude patterns representing their } \\
\text { institutional cultures }\end{array}$ & Attitude & $\begin{array}{l}\text { Have certain attitude patterns representing their } \\
\text { institutional cultures }\end{array}$ \\
\hline $\begin{array}{l}\text { Education and learning are essential for the } \\
\text { institutional development and orientation }\end{array}$ & Education & $\begin{array}{l}\text { Education and learning are essential for the } \\
\text { institutional development and orientation }\end{array}$ \\
\hline
\end{tabular}

Reference: James, B. G. (1989) Business World Wars: How to Implement the Military Strategies in the Market Fights? İlgi Publisher, Istanbul.

As seen in Table 1, firms and armies have similar understanding and implementations in many respects. From this context, it can be said that the comparison of Sun Tzu's principles with competition strategies may let the organizations and researchers get a different point of view. 


\subsection{Competition Strategies}

Competition is considered as a war which is made in order to get a competition advantage among the firms (Grant, 2005 , p. 92). What the firms aim at this war is to have more customers and a better position to manoeuvre. Similarly, Coulter (2005, p. 206-207) defines the competition as the war among the organizations made for the customers, the market share, the use of scant supplies, and the fulfilment of the objectives. For Hitt and et al. (2005), competition is a combination of actions that a firm develops and implements a strategy which has more value perception, which is difficult to imitate. From this point of view, the competition can be compared to the actions based on the mutual attacks and struggles in the battlefield.

Competition strategy consists of long-term actions related to the organization's obtaining a position where it will gain profit above the sector average and the organization's coping with five competition strengths (Porter, 1985). It also involves decisions and attitudes which set a high value for the customers through the basic cores the firm has in order to have a competition advantage (Hitt and et al., 1999). According to Lee \& Carter (2005), the competition strategy involves the actions which the firm does so as to maximize the advantages and minimize the disadvantages against its competitors.

The aim of the competition strategies is to provide a sustainable competition advantage for the organization in the long-term. To do this, the competition strategy chosen by the organization should be based on the supplies of the organization, its strengths and distinctive features, and it should be sustainable, perceived by the customers and difficult to be imitated by the competitors (Mitzberg, 1996; Morschetta and et al., 2006). When the literature of competition strategies is studied, it is seen that there are common points that strategy thinkers agree on. These common points include the attitudes towards especially the firms themselves, their competitors and the environment they are in such as evaluating the existing situation, showing the target, positioning and action (Taşgit \& K1lınç, 2008). Table 2 presents the information about basic competition strategies and their characteristics obtained from the literature scanning.

Table 2: Basic Competition Strategies, Their Characteristics and Factors Affecting the Competition Strategies

\begin{tabular}{|c|c|c|}
\hline Competition Strategies & Characteristics & Factors Affecting Competition Strategies \\
\hline - Cost Leadership & $\begin{array}{l}\text { - } \quad \text { Presenting the product with the least cost, } \\
\text { - } \quad \text { Big capital investments, } \\
\text { - } \quad \text { Bn aggressive pricing, } \\
\text { - } \quad \text { Beninning losses for the market share, } \\
\text { - } \quad \text { An acceptang from the experiences and the scale } \\
\text { - Investments for reducing the cost, } \\
\end{array}$ & $\begin{array}{l}\text { The characteristics and competition } \\
\text { structure of the sector where the firm is, } \\
\text { obstacles for entering-leaving the sector } \\
\text { The position, scale, management philosophy, } \\
\text { capital structure, basic cores and etc. of the } \\
\text { firm in the sector }\end{array}$ \\
\hline - Differentiation & $\begin{array}{l}\text { - } \quad \text { Presenting a unique product, } \\
\text { - } \quad \text { High pricing, } \\
\text { - } \quad \text { Difficulty in being copied, } \\
\text { - } \quad \text { Brand addiction, } \\
\text { - } \quad \text { Investments for increasing the value, } \\
\end{array}$ & $\begin{array}{l}\text { - The characteristics and competition structure of } \\
\text { the sector where the firm is, obstacles for } \\
\text { entering-leaving the sector } \\
\text { The position, scale, management philosophy, } \\
\text { capital structure, basic cores and etc. of the } \\
\text { firm in the sector }\end{array}$ \\
\hline - Focusing & $\begin{array}{l}\text { Implementing the cost leadership or one of the } \\
\text { differentiation strategies in a narrow market or } \\
\text { geographical area, }\end{array}$ & $\begin{array}{l}\text { - The characteristics and competition structure of } \\
\text { the sector where the firm is, obstacles for } \\
\text { entering-leaving the sector } \\
\text { The position, scale, management philosophy, } \\
\text { capital structure, basic cores and etc. of the } \\
\text { firm in the sector }\end{array}$ \\
\hline - Prospector & $\begin{array}{l}\text { Focusing on seizing new opportunities to be } \\
\text { offered in the market, } \\
\text { - Searching for the novelties all the time, } \\
\text { Focusing on developing new products/ service } \\
\text { in order to be able to get a competition } \\
\text { advantage in the changing environmental } \\
\text { conditions, } \\
\text { - Having the ability of manoeuvre difficult to } \\
\text { foresee }\end{array}$ & $\begin{array}{l}\text { - The characteristics and competition structure of } \\
\text { the sector where the firm is, the position, scale, } \\
\text { management philosophy, capital structure, } \\
\text { basic cores and etc. of the firm in the sector }\end{array}$ \\
\hline - Defence & - Having a limited and less varied product & - $\quad$ The characteristics and competition structure of \\
\hline
\end{tabular}




\begin{tabular}{|c|c|c|}
\hline & $\begin{array}{l}\text { structure and policy, } \\
\text { Focusing on protecting existence in a narrow } \\
\text { part of the market, } \\
\text { Searching for maintaining the status quo for the } \\
\text { market stability, } \\
\text { - Struggling with the limited number of products, } \\
\text { - Having an aggressive attitude to sustain the } \\
\text { things done well, }\end{array}$ & $\begin{array}{l}\text { the sector where the firm is, the position, scale, } \\
\text { management philosophy, capital structure, } \\
\text { basic cores and etc. of the firm in the sector }\end{array}$ \\
\hline - Analyzer & $\begin{array}{l}\text { Analyzing the products and implementations in } \\
\text { the potential market and copying them, } \\
\text { - Continuing to exist by copying the successful } \\
\text { implementations and ideas in the market, } \\
\text { - Not having a peculiar style of game and } \\
\text { destroying the others' games, }\end{array}$ & $\begin{array}{l}\text { - The characteristics and competition structure of } \\
\text { the sector where the firm is, the position, scale, } \\
\text { management philosophy, capital structure, } \\
\text { basic cores and etc. of the firm in the sector }\end{array}$ \\
\hline - Reactionary & $\begin{array}{l}\text { Not having a consistent strategic plan, } \\
\text { Mostly focusing on reacting because of not } \\
\text { having a solution since there is not a proper } \\
\text { means of competition, } \\
\text { Not being able to quickly respond to the } \\
\text { environmental changes due to not being } \\
\text { prepared in respect of sources and cores, } \\
\text { - Having to make compulsory changes, }\end{array}$ & $\begin{array}{l}\text { - The characteristics of the competition structure } \\
\text { of the sector where the firm is, obstacles for } \\
\text { entering-leaving the sector } \\
\text { The position of the firm in the sector, its scale, } \\
\text { management philosophy, capital structure, } \\
\text { basic cores and etc. }\end{array}$ \\
\hline - Resource Based & $\begin{array}{l}\text { Focused on basic cores and resources rather } \\
\text { than the outer environment of the firm, } \\
\text { Indexed to protect and improve the critical } \\
\text { resources all the time, } \\
\text { Always making investments to improve the } \\
\text { basic cores and values, }\end{array}$ & $\begin{array}{l}\text { - The cores and sources of the firm, } \\
\text { The structure and the characteristics of the } \\
\text { sector, } \\
\text { The structure of the product markets( active } \\
\text { and potential markets), } \\
\text { The characteristics of resource markets } \\
\text { (Finance, human being, raw material etc.), } \\
\text { - The other sectors ( similar or substitute } \\
\text { product/ relations with service sectors), }\end{array}$ \\
\hline - Merging & $\begin{array}{l}\text { - } \quad \text { Developing and gaining power, } \\
\text { - } \quad \text { Sharing the power, } \\
\quad \text { Protecting itself, }\end{array}$ & $\begin{array}{l}\text { - The characteristics, competition structure and } \\
\text { future tendencies of the sector, } \\
\text { - The position, scale, management philosophy, } \\
\text { finance structure, basic cores and etc. of the } \\
\text { firm in the sector, }\end{array}$ \\
\hline - Purchasing & $\begin{array}{l}\text { - Focused on developing in the same market, } \\
\text { Having the aim of entering new and } \\
\text { developing markets through purchasing, }\end{array}$ & $\begin{array}{l}\text { - The characteristics and future tendencies of the } \\
\text { sector, } \\
\text { The position, scale, management philosophy, } \\
\text { finance structure, basic cores, etc. of the firm in } \\
\text { the sector, }\end{array}$ \\
\hline - Preventing & $\begin{array}{l}\text { - Focused on preventing itself from the obstacles } \\
\text { of entering and leaving the market, } \\
\text { - Focused on preventing the future entries, }\end{array}$ & $\begin{array}{l}\text { - The characteristics and future tendencies of the } \\
\text { sector, } \\
\text { - The position, scale, management philosophy, } \\
\text { finance structure, basic cores, etc. of the firm in } \\
\text { the sector, }\end{array}$ \\
\hline
\end{tabular}

For the success of the competition strategies, primarily the main market (the battlefield) should be analyzed effectively. There are three main elements to be considered while analyzing the market. These are the structure of the market, determining the market limits and the life phase of the market. The structure of the market involves the number of the players in the market, the competitive situation and the level of difficulty in the market entries. Determining the market limits means determining the playground. The life phase of the market is related with the development of the market (Mirze \& Ülgen, 2005).

On the other hand, there are a lot of analyses of firms that stop operating as a result of losing the market struggle in the business world. In most of the evaluations, it is seen that the faults of the competition strategies preferred and implemented are emphasized. Table 3 shows the examples of war in the business world and underlines the main reasons of failure in the competition strategies. 
Table 3: Examples of War in the Business World and Reasons of Failure in the Competition Strategies

\begin{tabular}{|c|c|c|c|c|c|}
\hline Sector & Competitors & Issue & Strategy Implemented & Strategic Result & Reasons of Failure \\
\hline $\begin{array}{l}\text { Information } \\
\text { Technology }\end{array}$ & IBM-Remington & $\begin{array}{l}\text { Capturing the } \\
\text { market leadership }\end{array}$ & Differentiation & Market dominance & $\begin{array}{l}\text { The fault of } \\
\text { preparing for the last } \\
\text { attack rather than the } \\
\text { next one, }\end{array}$ \\
\hline $\begin{array}{l}\text { Automotive } \\
\text { Industry }\end{array}$ & $\begin{array}{l}\text { General Motors- } \\
\text { Japanese Firms }\end{array}$ & $\begin{array}{l}\text { Struggling for the } \\
\text { market share }\end{array}$ & Attacking- Eliminating & Market share loss & $\begin{array}{l}\text { The fault of despising } \\
\text { the importance of the } \\
\text { action and } \\
\text { exaggerating the } \\
\text { abilities, }\end{array}$ \\
\hline Razor & Gillette-BIC & $\begin{array}{l}\text { Struggling for the } \\
\text { market share }\end{array}$ & Attacking-Defending & Market share loss & $\begin{array}{l}\text { The fault of relying } \\
\text { on bigness and } \\
\text { resources rather than } \\
\text { being quick }\end{array}$ \\
\hline Banking & $\begin{array}{l}\text { HSBC, Fortis, } \\
\text { Citibank, } \\
\text { Bankeuropa- } \\
\text { Akbank }\end{array}$ & $\begin{array}{l}\text { Struggling for the } \\
\text { market share }\end{array}$ & $\begin{array}{l}\text { "Partnership" with } \\
\text { international finance } \\
\text { monopolies }\end{array}$ & Market share loss & $\begin{array}{l}\text { The fault of being } \\
\text { caught unprepared } \\
\text { and loosening up, }\end{array}$ \\
\hline Textile & $\begin{array}{l}\text { MCM Textile, } \\
\text { Europe Textile, } \\
\text { Esstri Textile, } \\
\text { Yilfa Textile, } \\
\text { Develi textile } \\
\text { Firms-China }\end{array}$ & $\begin{array}{l}\text { Struggling for the } \\
\text { market share }\end{array}$ & Attacking- Eliminating & $\begin{array}{l}\text { Stopping } \\
\text { manufacturing due } \\
\text { to competition }\end{array}$ & $\begin{array}{l}\text { The fault of } \\
\text { preferring the } \\
\text { classical methods } \\
\text { instead of novel } \\
\text { strategies, }\end{array}$ \\
\hline $\begin{array}{l}\text { Automobile } \\
\text { Spare Parts } \\
\text { Manufacturer }\end{array}$ & $\begin{array}{l}\text { Al-Ko Condural } \\
\text { (German)-Export } \\
\text { Firms in Gebze } \\
\text { and Bursa } \\
\text { (Turkey) }\end{array}$ & $\begin{array}{l}\text { Struggling for the } \\
\text { market share }\end{array}$ & Low Price & $\begin{array}{l}\text { Declaring } \\
\text { Bankruptcy }\end{array}$ & $\begin{array}{l}\text { The fault of thinking } \\
\text { "I won the whole } \\
\text { struggle" after } \\
\text { winning the first } \\
\text { attack, }\end{array}$ \\
\hline $\begin{array}{l}\text { Public } \\
\text { Transport }\end{array}$ & $\begin{array}{l}\text { Varan and Ulusoy- } \\
\text { BOSS Tourism }\end{array}$ & $\begin{array}{l}\text { Struggling for the } \\
\text { market share }\end{array}$ & $\begin{array}{l}\text { The Cost Leadership with } \\
\text { Low Price }\end{array}$ & $\begin{array}{l}\text { Stopping the } \\
\text { Operation }\end{array}$ & $\begin{array}{l}\text { The fault of not } \\
\text { admitting that they } \\
\text { had made/would be } \\
\text { able to make a } \\
\text { mistake, }\end{array}$ \\
\hline
\end{tabular}

The implementation of competition strategies involves a variety of competitive actions. These are defence and attack oriented actions. Attack oriented actions are the ones that the firm do against its competitor to make its competitive position stronger when the firm feels stronger. Defence oriented actions are the reactions of the firm to its competitors' attacks to protect the competition advantage that it has (Coulter, 2005, p. 206-207).

\subsection{Sun Tzu’s War Art Principles}

In his book called "The Art of War", Sun Tzu puts an emphasis on 14 basic war principles to beat the enemies. In Table 4, information about the principles and their characteristics is presented. 
Table 4: Sun Tzu's War Art Principles and Their Characteristics

\begin{tabular}{|c|c|}
\hline 1) Strategy and Planning, & $\begin{array}{l}\text { The most important characteristic is being unknown, beating without fighting and } \\
\text { making the most work with the least effort. The main philosophy in the strategy is } \\
\text { "Deep knowledge, strong action". }\end{array}$ \\
\hline 2) Leadership, & $\begin{array}{l}\text { It is related with being able to analyze every movement of the enemy (competitor) } \\
\text { and acting in harmony against the events happening. A strategic leader should see } \\
\text { what the others cannot see and know what the others do not know. }\end{array}$ \\
\hline 3)Environmental Conditions, & $\begin{array}{l}\text { It is about the conditions of climate and region where the organization is, basic cores } \\
\text { it has and having correct and detailed information about the characteristics of the } \\
\text { competitors. }\end{array}$ \\
\hline 4) The Structure and Culture of the Organization, & $\begin{array}{l}\text { It is evaluated as the liveable structures where there is a high level of harmony } \\
\text { between the levels of the army, commanders and soldiers, where the army and } \\
\text { soldiers have the same aims and which can adjust to changeable environmental } \\
\text { conditions. }\end{array}$ \\
\hline 5) Strategic Values, & $\begin{array}{l}\text { It is the combination of five elements: Battlefield, Route, Weather Conditions, } \\
\text { Leadership and Discipline. }\end{array}$ \\
\hline 6) Movement Style (Struggle), & $\begin{array}{l}\text { It is related with determining how an army will fight with its enemies. That means } \\
\text { the best action is the one which is not expected. }\end{array}$ \\
\hline 7) Forming Opposing Sides, & It involves positioning and forming the war order. \\
\hline 8) Strength, & It consists of all resources and equipment that the army can use against the enemies. \\
\hline 9) Comparison, & $\begin{array}{l}\text { It is related with determining the regions which the army can/can not defend and } \\
\text { comparing them with the enemies'. }\end{array}$ \\
\hline 10) Adapting, & $\begin{array}{l}\text { It is the army's not relying on certain methods and its changing according to the } \\
\text { events. }\end{array}$ \\
\hline 11) The Structure and Conditions of the Area, & $\begin{array}{l}\text { It involves the present and future characteristics of the battlefield where the army } \\
\text { fights, and struggle (competition) conditions. }\end{array}$ \\
\hline 12) Ground, & It is related with the battlefield and conditions which will determine the action style. \\
\hline 13) Starting a Fire, & $\begin{array}{l}\text { It consists of tactics which are used to catch the enemies unprepared, force them to } \\
\text { react and be able to attack them in this way. }\end{array}$ \\
\hline 14) Using a Spy, & $\begin{array}{l}\text { It means knowing the abilities and the situation in which the competitors (enemies) } \\
\text { are for an effective struggle. }\end{array}$ \\
\hline
\end{tabular}

\section{Methodology}

The method of this study was designed on creating a relational approach through literature review. During this period, the competition strategies were examined primarily and categorized under eleven headings. Later, these strategies were conducted with thirteen arts of war principles belonging to sun Tzu. This connection was made by determining how the principles might contribute to the formation and implementation of the competition strategies. In addition, which principle might support which features of the competition strategies was explained. Before making the connection, a conceptual fragment was formed for the terms used in the book so as to adapt Sun Tzu's war art principles to the study. According to this conceptual fragment, the matching is as follows: War - Competition, Enemies - Competitors, Environmental Conditions - Elements affecting the competition environment and the management and decisions of the company, Battlefield - Market, Weapons - Means used in the strategy construction of the organization and in the implementation of the strategies. 


\subsection{Research Goal}

This study aims to put forward proposals that will be able to form a fresh perspective for the business world and the literature by establishing a contact between the basic characteristics of the competition strategies and Sun Tzu's war art principles. In order to fulfil this aim, Sun Tzu's book called "The Art of War" was investigated in respect of competition and the studies on this subject were comprehensively evaluated.

\subsection{Comparing Sun Tzu's War Art Principles with Competition Strategies}

When we take the management literature into consideration, we see that there are important clues for comparing the competition strategies with the war art principles. Strategy is the combination of long-termed, dynamic decisions which are focused on the result, which are formed by observing the actions and behaviours of the competitors in order that the organization can fulfil certain vital aims. As a military term, strategy means the art of planning and managing the tactics and fighting methods that an army will display during a war. The aim at implementing a strategy is to gain the result by using the present resources in the most effective and productive way. The position of the competitors, searching for the quality and quantity of the equipment to be used, the structural characteristics of the battlefield, getting information about opportunities and threats, determining your weaknesses and strengths are the concepts that form the base of the strategy and act important roles in the success (Mirze \& Ülgen, 2005). Strategies are formed by considering the possible actions of the competitors, the future forms of the environmental factors. There is no need for a comprehensive competition strategy if a competitor (enemy) does not exist and the environmental factors do not affect the future and today of the organization. Plans are prepared and put into practice. However, it is impossible to find such an environment in the globalising world. The environment where today's organizations are is described as the "hyper competition" environment (D'aveni, 2005). It is inevitable to disappear if you cannot struggle against the changing competitive conditions. Hence, the organizations should always consider the principles of war art.

When Sun Tzu's war art principles are taken into consideration, it is understood that an ideal competition strategy makes it necessary for the organization to have detailed information about the environmental variables, to analyze itself and to determine the basic cores. Besides, it needs planned tactics to manage the future that requires a flexible organizational structure, plan and policies that can be adjusted to all possible situations. In view of the things said above, it can be suggested that, in today's competitive conditions, the firms should benefit from Sun Tzu's war art principles in a more effective way to have a more combative point of view in forming their competition strategies.

According to Sun Tzu's war art principles, it is essential to have commanders who can analyze every attack of the enemy spontaneously, adapt to changing conditions completely and foresee an event before it happens in order to be successful in a war. Strategic Management Literature also lays great emphasis on the need for the strategy leaders in today's competitive world. In literature, the strategic leadership is defined as the ability of predicting the future, forming a vision, being flexible, thinking strategic and working with others cooperatively so as to fulfil the changes to make the organization gain a strong future (Ireland \& Hitt,2002:4). As a result, it can be said that predicting the future, adaptation to the changes, flexibility and cooperation based on synergy are the basic features to form and implement the competition strategies effectively. Therefore, when the scope and factors effective in the success of the competition strategies are considered, it can be stated that the characteristics of the leadership which is one of the principles of Sun Tzu's war art are related with the competition strategies.

According to Sun Tzu's war art principles, knowing the environmental conditions is the same as winning the battle. Knowing the environmental conditions is connected with climate, area and weather conditions, human resources, equipment to be used in the war and timing. From the extent of strategic management, the organizations have a continuous relation with their environment like a living organism. With their attitudes they are either affected by the environment or force the environment to change by affecting it. From this respect, the analysis of the environmental conditions is one of the most important processes in the stage of forming and implementing strategies. According to the strategic management literature, the formulation of the strategies is related with the comparison of the cores that an organization has and the conditions of the environment where it operates. For Fitzroy \& Hulbert (2005, 57), environmental analyses provide active and compulsory inputs to develop a strategy and help the firm to determine attractive opportunities and to decide where and how to compete. Johnson and Scholes (1993, p. 76) evaluate the analysis of environmental conditions in five stages. These are (I) Determining the basic characteristics of the 
environmental conditions, (II) Observing the effects of the environmental conditions, (III) Determining the basic competition strength factors, (IV) Determining the strategic position of the firm and (V) Determining the basic opportunities and threats. The elements such as the structure of the environment of the organization, stabilitydynamism-chaos-definiteness-indefiniteness, the actions- tactics and attack-defence times of the competitors will affect the operation style, struggle form, aims and objectives, resource allotment, adaptation and success of the organization. Analyzing each of these stages will enable the organization to get to know itself, to determine its weaknesses and strengths and to see the opportunities and threats. Therefore, it can be said that there is an important relation between the success of the competition strategies and how the organization affect or is affected by the environmental conditions. In view of what is mentioned above, it can be claimed that the analysis of the environmental conditions which is one of Sun Tzu's war art principles is related with the formation and implementation of the competition strategies in a great deal.

Operation style is related with putting the strategies into practice. In general it is explained as responding the attitudes of the competitors or reacting by forcing the competitors to act. According to the principles, you need to have unexpected attitudes in order to have an irresistible competition strategy. Pretending to be weak when you are strong, scattered when you are not scattered, slow when you are fast, behind when you are ahead and to have little when you have a lot can be given as examples of these attitudes. Related with this, it can be urged that the operation style, which is one of Sun Tzu's war art principles, is connected with the success of the competition strategy especially in practice.

Adaptation and flexibility are important in competition strategies since they are formed to predict and manage the future in the environmental conditions which there is a lot of uncertainty. According to the principles, adaptation means not depending on certain methods and changing according to the events. So as to have success, it is necessary to figure out all cases that can be faced in negative and positive conditions and the best and worst probabilities, and to provide the flexibility for the organization to adapt these situations.

As the principles state, one of the elements in achieving the victory is forming opposing sides - in other words positioning. Positioning is the most crucial point to reach in order to respond the competitors' attacks in the most effective way. The distance between this point and the position where the firm is now determines the possibility of success. The aim of the competition strategies developed is to reach this point and to come to a position where it is impossible to be competed with.

Another important factor which will affect the success of the firm is the competition environment which the firm is in. Sun Tzu defines this concept as "ground" and mentions the most suitable and unsuitable ground types to attack and defend. The competition environment where the firm is consists of the number of the firms in the sector where the firm operates, the number of the active competitors, the success factors affecting the competition, future trends, the intensity and way of the competition. What is important for the firm is to know how it will obtain the factors affecting the competition strength, which competitor it will become close to, with which competitor it will cooperate, which competitor it will attack, from which competitor it will defend itself. These competition environments are generally called as monopolistic, oligopolistic markets in the marketing literature. The analysis of the competition environment effectively is one of the most crucial stages of the competition strategies in achieving the success.

The other element for an effective competition strategy is primarily to get the critical information about the competitor's abilities and the situation which the competitor is in. Sun Tzu suggests the method of using a spy for this concept which is defined as "competitor analysis" in the literature and mentions five types of spy. It is essential for the success to identify the spy who you use to analyze your competitor and the spy who the competitor uses to analyze you and to use this spy for your benefit. It is seen as the most effective weapon to send wrong information (peculiar to one time) especially at the most crucial points. Finally, it is understood that to choose a tactical operation style that will force the competitor to react unexpectedly and in an unplanned way (starting a fire) is connected closely to timing which is another characteristic the competition strategy must have.

As a result of these evaluations, it is thought that Sun Tzu's war art principles and the competition strategies have a common philosophy. Table 5 shows the specific information about this common philosophy between these concepts. 
Table 5: Sun Tzu's War Art Principles and Competition Strategies

\begin{tabular}{|c|c|c|}
\hline Sun Tzu's Principles & Common Philosophy & $\begin{array}{c}\text { Basic Principles in Forming and } \\
\text { Implementing Competition Strategies }\end{array}$ \\
\hline - Strategy and Planning & $\begin{array}{l}\text { How to use the present resources in the most effective } \\
\text { and productive way for a strong attack against the } \\
\text { competitor? }\end{array}$ & Planning \\
\hline - Leadership & $\begin{array}{l}\text { Being able to predict the future, form a vision, be } \\
\text { flexible, think strategic and changes that will be able to } \\
\text { make the organization gain a strong future }\end{array}$ & Effective Leadership of the Top Management \\
\hline $\begin{array}{l}\text { - Adaptation to Environmental } \\
\text { Conditions }\end{array}$ & $\begin{array}{l}\text { The comparison of cores the organization has with the } \\
\text { environmental conditions the organization operates in } \\
\text { and making the organizational changes in a proactive } \\
\text { and harmonious way }\end{array}$ & Environmental Analyses \\
\hline $\begin{array}{l}\text { - Organization Structure and } \\
\text { Organization Culture }\end{array}$ & $\begin{array}{l}\text { Forming an organization structure congenial with the } \\
\text { changes, focused on success and improving the culture }\end{array}$ & Structure and Culture congenial with the Aim \\
\hline - Having Strategic Values & $\begin{array}{l}\text { Capturing and protecting the crucial resources that will } \\
\text { make the organization different }\end{array}$ & $\begin{array}{l}\text { Unique resources providing a competition } \\
\text { advantage }\end{array}$ \\
\hline $\begin{array}{l}\text { - Area Conditions and } \\
\text { Operation Style (Fighting) }\end{array}$ & $\begin{array}{l}\text { Being sensitive to environmental conditions and } \\
\text { determining the most effective fighting style }\end{array}$ & $\begin{array}{l}\text { Determining the struggle type congenial with } \\
\text { the characteristics of the organization }\end{array}$ \\
\hline - Positioning & Choosing the most advantageous position for success & Determining the position in the sector \\
\hline - Manoeuvre & $\begin{array}{l}\text { Having the ability of efficient acting against the } \\
\text { unexpected situations (Emerging) }\end{array}$ & Organizational flexibility \\
\hline - Comparison & Determining the weaknesses and strengths & Competitor Analysis \\
\hline - Adaptation & Flexibility in the methods of struggle & $\begin{array}{l}\text { Having alternative methods that will make the } \\
\text { organization successful }\end{array}$ \\
\hline - Management and Control & $\begin{array}{l}\text { Analysing the results of the operations and making the } \\
\text { necessary arrangements }\end{array}$ & Performance Evaluation \\
\hline - $\quad$ Starting a Fire & $\begin{array}{l}\text { Fulfilling operations that will catch the competitor } \\
\text { unprepared }\end{array}$ & Forcing the competitor to attack \\
\hline - Using a Spy & $\begin{array}{l}\text { Finding and using the equipment and people to get the } \\
\text { necessary information for success }\end{array}$ & Collecting and using information and data \\
\hline
\end{tabular}

\section{Conclusion}

Competition strategies, as stated in the sections above, are related with the main strategy, manoeuvre and tactics for the firm to fulfil its objectives. It is closely connected with the aim-target, mission-vision of the organization. It is formed according to the basic cores and strategic position that the firm has. It requires strategic leadership because of its scope. The means used successfully in the implementation (intellectual capital, technology, and etc.) are very important. It is a concept which needs social responsibility and ethical rules should be considered in the development and implementation stages. Some elements appear to be the most urgent things to develop and implement competition strategies successfully. Getting detailed information about the situational (outer and inner) environment, making competitor analyses, and parallel to that, making strategic attacks, winning without fighting, reaching a strong strategic position through basic cores, having flexible plans and policies and the ability of performing sudden manoeuvres can be given as examples.

As Sun Tzu's war art principles are military based strategies, it can be regarded as strange to evaluate the organizations in respect of competition strategies at first. However, when the concepts are studied in a detailed way, it is understood that these principles give essential information about developing and implementing competition strategies especially in competitor analysis, reacting and adapting to environmental conditions, the ability of manoeuvre, tactical changes, resource allotment and leadership.

The study can be perceived to be limited since the competition strategies implemented in the organizations are evaluated with military strategies. Nevertheless, if it is thought that the business world today is indefinite and the 
setting for mutual attacks and strategies like a battlefield and most concepts used in the strategic management are related with military terms, with this study it is aimed at giving a different point of view.

It is thought that each of war art principles should be investigated comprehensively with the strategic management point of view in the studies that will be carried out in the future. Carrying out empirical studies displaying the importance level of these principles in implementation will enable the subject to be understood better.

\section{References}

1. Bono, E.D. (1992), Sur/petition, Harper Collins Publisher Inc.

2. Coulter, M. (2005), Strategic Management in Action, Pearson Education International Inc. Upper Saddle River, New Jersey. 3th Edition.

3. D'aveni, R.A. (With Gunther, R.) (1994), Hypercompetition: Managing The Dynamics of Strategic Maneuvering. Maxwell Macmillan Canada Inc. The Free Press.

4. Fitzroy, P \& Hulbert, J. M. (2005). Strategic Management:Creating Value in A Turbulent World. John Wiley \& Jons Inc. U.K.

5. Grant, R.M. (2005). Contemporary Strategy Analysis. Backwell Publishing (UK). 5th Edition.

6. Hitt, A.M. and Ireland, R.D. (2002). The Essence of Strategic Learship: Managing Human and Social Capital. The Journal of Leadership and Organizational Studies, Vol : 9, No: 1, pp. 3-14.

7. Hitt, A.M., Ireland, R.D. \& Hoskisson, R.E. (2005). Strategic Management: Competitiveness and Globalization (Concepts and Cases). Thomson Corporation, South-Western, 6th Edition.

8. Ilıcak, G. and Özgül, R. (2005). Sun Tzu Savas Sanatına Göre, Marka Pazar Stratejilerinin Belırlenmesı. Journal of İstanbul Kültür University. 2005/1, pp. $95-105$.

9. Johnson, G. \& Scholes, K. (1993). Exploring Corparate Strategy, Simon \& Schuster, Prentice Hall International (UK).

10. Kolar, T. and Toporišic, A. (2007). Marketing as warfare, revisited. Marketing Intelligence \& Planning, 25 (3), pp. 203 - 216.

11. Lee, S.F., \& Ko, A.S.O. (2000). Building balanced scorecard with SWOT analysis, and implementing Sun Tzu's The Art of Business Management Strategies on QFD methodology. Managerial Auditing Journal. 15 (Issue: 1/2), pp. 68 - 76.

12. Lee, K. \& Carter, S. (2005). Global Marketing Management: Changes, Challenges and New Strategies. Oxford University Press Inc. New York.

13. Lee, S.F., Roberts, P., Lau W.S. \& Bhattacharyya, S.K. (1998). Sun Tzu's as business and management strategies for world class business excellence evaluation under QFD methodology. Business Process Management Journal, 4 (2), pp. 96 - 113.

14. Lin, J-H. (1994). Discussions about Sun Tzu's thought of strategy formulation and implementation. The Chinese Journal of Administration, Vol. 55, pp.17-28.

15. Lo, V.H.Y., Ho, C.O. \& Sculli, D. (1998). The strategic insights of Sun Tzu and quality management. The TQM Magazine, 10 (3), pp. 161 168

16. Mintzberg, H., (1996). Generic business strategies. In: Mintzberg, H., Quinn, J. (Eds.), The Strategy Process, Prentice Hall International, Upper Saddle River/NJ.

17. Morschetta, D., Swobodab, B. \& Schramm-Klein, H. (2006). Competitive strategies in retailing-an investigation of the applicability of Porter's framework for food retailers. Journal of Retailing and Consumer Services, Vol:13, pp. 275-287.

18. Porter, M. (1980). Competitive strategy, New York: The free press.

19. Porter, M. (1990). The competitive advantage of nations, New York: The free press.

20. Porter, M. E. (1985). Competitive advantage: creating and sustaining superior performance. New York: The Free Press.

21. Prahald, C.K., \& Hamel, G. (1990). The Core Competence of Corporations. Harvard Business Review, May-June, 68 (3), pp. $79-91$.

22. Tsang, Y.S. \& Lee, S.F. (2002). A study on Sun Pin's art of business management strategies matching the MBNQA criteria for business competitiveness. Integrated Manufacturing Systems, 13 (6), pp. 386 - 407.

23. Ülgen, H. \& Mirze, S. K. (2004). İsletmelerde Stratejik Yönetim. Literatür yayıncılık. İstanbul.

24. Wee, C-H., Lee, K-S. \&Hidajat, B.W. (1991). Sun Tzu War \& Management, Addison-Wesley, Reading, MA.

25. Wee, C.H. (1994). Sun Tzu's art of war selected applications to strategic thinking and business practices. International Review of Strategic Management, Vol. 5, pp. 83-109.

26. Wu, W.Y., Chou, C. H. \& Wu, Y.J. (2004). A study of strategy implementation as expressed through Sun Tzu's principles of war. Industrial Management \& Data Systems, 104 (5), pp. 396-408. 